\title{
Comparison of Cleavage Rate of Buffalo Oocytes on Supplementing with Different Concentration of Serum Gonadotropin, Estradiol 17b, Estrus Buffalo Serum and Buffalo Follicular Fluid
}

\author{
Ambadas $^{1 *}$, K. Shrikant ${ }^{1}$, G. Sarvadnya ${ }^{2}$ and K. B. Satish ${ }^{1}$ \\ ${ }^{1}$ Department of Veterinary Physiology and Biochemistry, Veterinary College, Bidar, India \\ ${ }^{2}$ Veterinary Officer, Veterinary Dispensary Donagapur Tq Bhalki Dist Bidar, India
}

*Corresponding author

Keywords

Cleavage rate, Oocytes, Serum gonadotropin, Follicular fluid

Article Info

Accepted:

15 January 2020

Available Online:

10 February 2020

\section{A B S T R A C T}

Serum gonadotropin@50 and 100IU/ml, estrodiol-17 $@ 0.5$ and 1 $\mu \mathrm{g} / \mathrm{ml}$, EBS @5 and 10\% and BFF @5 and 10\% supplementation Iis done on cleavage rate of buffalo oocytes for the comparison of efficacy of hormones. Ovaries were collected from buffaloes slaughtered at local abattoir. Oocytes were aspirated and good and excellent quality oocytes were matured in basic maturation media TCM199 supplementing above mentioned supplements separately. The recovery rate of culturable oocytes was $85.33 \%$. The highest cleavage rate was documented with supplementation of $10 \%$ EBS and the lowest was observed with $10 \%$ BFF. The cleavage rate was significantly $(\mathrm{p} \leq 0.05)$ higher in the group supplemented with 5\%EBS and 10\% EBS as compared to all other groups of the experiment. It can be concluded that the supplementation of EBS to IVM medium has positive effect on cleavage rate.

\section{Introduction}

The buffalo forms the backbone of India's dairy industry and is considered as the 'bearer cheque' of the rural flock and India's milking machine (Balain, 1999). As per the $19^{\mathrm{th}}$ livestock census India has around 108.7 million of buffalo population and constitutes around $21.23 \%$ of total livestock population. Buffalo population of Karnataka is 33.06 lakhs. Buffalo contributes 51\% (132430 tonnes) of total nation's milk production and around 1103.85 tonnes of meat production of total nation's meat production (Department of Animal Husbandry Dairying and Fisheries, ministry of agriculture, New Delhi, 2014).

The buffalo is the predominant domestic animal for milk and meat production. On average, buffalo is four times as productive as 
an average indigenous cow in India. India has world's best buffalo dairy breeds and provides superior buffalo germplasm to several countries of the world (Kaikini, 1992).

The domestic water buffalo plays a key role in milk production in many Asian countries including India, and they are able to withstand the adverse environmental conditions of the tropics. However the buffalo are traditionally considered to have a low reproductive efficiency (Pankaj, 2015). The low reproductive efficiency in female buffalo can be attributed to delayed puberty, higher age at calving, long postpartum anoestrus period, long calving interval, lack of overt sign of heat, and low conception rate. In addition, female buffaloes have few primordial follicles and a high rate of follicular atresia. These factors are responsible for driving a large number of buffaloes to slaughter house either prior to maturity or after calving, which has resulted in enormous loss of genetic resources and significant decline in their number in recent years. Thus there is a need to improve reproductive performances of buffaloes.

In vitro maturation (IVM) of oocytes and in vitro fertilization (IVF), in vitro culture of embryos and embryo transfer technology appear to be useful techniques for the improvement of reproductive efficiency of buffaloes (Uma, 1997). Embryo transfer technology has made rapid strides in dairy cattle industry and has become viable commercially in some of advanced countries. Therefore, the emphasis has now shifted to in vitro embryo production (IVEP)as it can salvage the genetic potential from infertile female and can yield large number of embryos (Kumar and Anand, 2012). Ovaries of the slaughtered animals are the cheapest and the most abundant source of primary oocytes for large scale production of embryos through in vitro maturation (IVM) and in vitro fertilization (IVF) (Agrawal et al., 1995).
In vitro maturation (IVM) is the one of the essential step and starting point for lot of biotechnological applications in animals like in vitro fertilization (IVF), cloning, transgenic animal production and embryonic stem cell research. Oocytes maturation is the process of complex changes in the protein phosphorylation which transform the primary oocytes in to mature secondary oocytes. Maturation of the oocytes included two aspects viz., nuclear and cytoplasmic maturation. The nucleus and the cytoplasm of the oocytes undergo many changes during maturation, making it receptive to fertilization and competent to support embryonic development (Tomek et al., 2002).

Several workers have studied different aspects of IVM in mammalian oocytes. In most of the studies revealed that media designed originally for cell culture, are not capable of supporting high levels of oocytes maturation and, therefore, are commonly supplemented with sera and hormones, growth factors and antioxidants to improve the maturation rates at high level (Kumar and Anand, 2012). The maturation medium with the selection of protein supplements, hormones for IVM play an important role in subsequent IVF and in vitro development.

The identification of substances capable of delaying the nuclear maturation time and thus allowing cytoplasmic and nuclear changes to occur synchronously has been the subject of several studies. Follicular fluid (FF), consisting of electrolytes, hormones, amino acids, growth factors, among other components, has been used as a natural substance for blocking the meiosis (Aguilar et al., 2001). Some studies have documented that maturation medium supplemented with FF provides appropriate environment to bovine oocytes development (RomeroArredondo and Seidel, 1996), since it increases the degree of cumulus cells 
expansion (Aguilar et al., 2001) and enhances the embryonic development (Algriany et al., 2004).

Supplementation of serum in media had favourable effect on maturation. The serum contains a number of known growth factors that have an important role in the regulation of oocyte maturation, particularly via cumulus cells, it also prevents the hardening of the zona pellucida; moreover, the beneficial action of serum may be due to its antioxidant properties (Mahmoud and Nawito, 2003). Estrus buffalo serum (EBS), a rich source of hormones and growth factors, could be used to improve the developmental competence of buffalo oocytes culture in vitro (Abid et al., 2008).

An attempt to induce in vitro maturation can only be successful in conditions that are similar to those existing in vivo. Therefore, the biochemical composition of the oocyte culture media has great influence on the success rate of in vitro maturation. Since, under in vivo conditions the oocytes maturation is influenced by various steroid and gonadotropic hormones, it is necessary to supplement the steroid and hormones to the medium in order to sustain the growth and development of oocytes either by directly or through the hormone rich serum medium. Therefore the development of a suitable culture system and components of maturation media for in vitro maturation of oocytes is a major component of the in vitro embryo production procedures.

Perusal of literature indicates less number of works on optimizing the in vitro maturation of buffalo oocytes as compared to the other species.

Considering all these points present study was designed to investigate the effect serum gonadotrophin, estradiol-17 $\beta$, estrous buffalo serum (EBS) and buffalo follicular fluid (BFF) supplementation on CLEAVAGE rate with the following objective

\section{Materials and Methods}

\section{Materials}

\section{Media, chemical and plastic wares}

All the media and chemicals were procured from Himedia Laboratories, Mumbai unless otherwise stated. Folligon ${ }^{\circledR}$ (Pregnant Mare Serum Gonadotrophin, 1000IU/vial) and Chorulon ${ }^{\circledR} \quad$ (Human Chorionic Gonadotrophin, 1500IU/vial) were purchased from Intervet International B.V., Boxmeer, Netherland. The disposable plastic wares used in this experiment were obtained either from Tarsons Products Private Limited, Kolkota or from Himedia Laboratories, Mumbai.

All the media were prepared by using sterile tissue culture grade water. All the working solutions/media excluding OCM were kept for at least $3-4 \mathrm{hr}$ in $\mathrm{CO}_{2}$ incubator at $38^{\circ} \mathrm{C}$, $5 \% \mathrm{CO}_{2}$ and $95 \%$ relative humidity for quenching before use. Prepared OCM was kept in BOD at $37^{\circ} \mathrm{C}$. The stocks of media were stored at $4^{\circ} \mathrm{C}$ and used within one month.

\section{Sterilization procedures}

Sterilization of all media was done by filtering through $0.2 \mu \mathrm{m}$ syringe driven filters. The glassware and micropipette tips were sterilized by autoclaving at $121^{\circ} \mathrm{C}$ for $30 \mathrm{~min}$. Fresh sterilized and disposable culture bottles, petridishes, tubes and syringe were used every time. All the equipments were exposed to UV light for 15 minutes before use. In order to avoid bacterial and fungal contamination all the procedure except the aspiration of oocytes, starting from oocyte searching to in vitro culture works and media preparation 
were carried out in highly sterile condition under laminar flow cabinet.

\section{Preparation of buffalo serum and estrous buffalo serum (EBS)}

The blood was collected from jugular vein of normal cycling buffaloes that are not in estrus as well as from the buffaloes that are in estrus for the separation of buffalo serum and estrus buffalo serum respectively. The collected blood was kept in slant position and allowed to clot, later blood was centrifuged at $3000 \mathrm{rpm}$ for $15 \mathrm{~min}$ for serum separation. The separated serum was heat inactivated at $56^{\circ} \mathrm{C}$ for $30 \mathrm{minutes}$, filtered through $0.45 \mu \mathrm{m}$ filter and stored at $-20^{\circ} \mathrm{C}$ in $2.0 \mathrm{ml}$ micro centrifuge tubes as aliquots for future use. Same batch of pooled serum was used for all the trials. The buffalo serum was used in the preparation of working oocyte collection medium (OCM) where as EBS was used as supplement in T5 and T6 groups.

\section{Collection of buffalo follicular fluid (BFF)}

Ovaries were collected immediately after slaughter of buffaloes of unknown reproductive status at the local abattoir. The ovaries were maintained in a thermos flask containing warm $\left(35-37^{\circ} \mathrm{C}\right)$ normal saline $(0.9 \% \mathrm{NaCl})$ fortified with $50 \mu \mathrm{g} / \mathrm{ml}$ gentamycin sulphate (Gentalab). The ovaries were transported to the laboratory within $2 \mathrm{hrs}$ after slaughter of animals. At the laboratory, the buffalo ovaries obtained from the abattoir were rinsed thoroughly with fresh sterile normal saline supplemented with gentamycin @ 50 $\mu \mathrm{g} / \mathrm{ml}$ 5-6 times and final wash was done with Phosphate buffered saline (PBS). Follicular fluid was aspirated from non atretic, surface follicles $(>3 \mathrm{~mm}$ diameter) of the ovaries using $5 \mathrm{ml}$ syringe attached with 18-gauge needle. The pooled follicular fluid was allowed to settle for 10mins and the supernatant was collected. The collected follicular fluid was sterilized by filtering through $0.22 \mu \mathrm{m}$ syringe driven filter and stored in sterile micro centrifuge tubes of $2.0 \mathrm{ml}$ capacity at $-20^{\circ} \mathrm{C}$ for subsequent use for IVM as supplement in T7 and T8 groups.

\section{Collection of ovaries and semen sample}

Buffalo ovaries were collected immediately after slaughter of the animals of unknown reproductive status at the local abattoir. The ovaries were maintained in a thermos flask containing warm $\left(35-37^{\circ} \mathrm{C}\right)$ normal saline $(0.9 \% \mathrm{NaCl})$ fortified with $50 \mu \mathrm{g} / \mathrm{ml}$ gentamycin sulphate (Gentalab). The ovaries were transported to the laboratory within $2 \mathrm{hrs}$ after slaughter of animals.

The frozen buffalo bull semen straws supplied by Department of Animal Husbandry and Veterinary Services, Government of Karnataka to the Department of Veterinary Gynaecology and Obstetrics, Veterinary College, Bidar were utilized for in vitro fertilization.

\section{Methods}

\section{Oocytes collection, processing and grading}

Ovaries were collected immediately after slaughter of adult female buffaloes of unknown reproductive status at the local abattoir. The ovaries were maintained in a thermos flask containing warm $\left(35-37^{\circ} \mathrm{C}\right)$ normal saline $(0.9 \% \mathrm{NaCl})$ fortified with $50 \mu \mathrm{g} / \mathrm{ml}$ gentamycin sulphate. The ovaries were transported to the laboratory within $2 \mathrm{hrs}$ after slaughter of animals. In the laboratory, ovaries were washed 6-7 times in warm normal saline solution $\left(37^{\circ} \mathrm{C}\right)$ fortified with antibiotic and final two washings with PBS. Washed ovaries were submerged in PBS solution in sterile beaker and were used for oocyte collection. Oocytes were aspirated from all visible non atretic follicles $(2-8 \mathrm{~mm}$ in 
diameter) by an 18gauge needle attached to $5 \mathrm{ml}$ sterile disposable syringe (Dispovan, India) containing $0.5 \mathrm{ml}$ oocyte collection media (OCM) (Appendix-I). The cumulus oocyte complexes (COC) along with follicular fluid was pooled into $50 \mathrm{ml}$ sterile plastic tube containing $1-2 \mathrm{ml} \mathrm{OCM}$ at $37^{\circ} \mathrm{C}$ and were allowed to settle for 10 minutes.

Finally the sediments were taken in large petridish $(90 \mathrm{~mm})$ and oocytes were searched under zoom stereo microscope (Motic, Germany). The cumulus oocyte complexes (COC) were isolated, evaluated and graded. Only excellent ( $>5$ layers of cumulus cells and evenly granulated cytoplasm) and good (>3 layers of cumulus cells and evenly granulated cytoplasm) COC were collected and washed several times in OCM followed by maturation media (MM)

\section{In vitro maturation of oocytes}

Graded oocytes were washed in respective maturation media for 4-5 times. After washing, 15-20 oocytes were cultured in 50 $\mu 1$ droplets of respective maturation media in $35 \mathrm{~mm}$ sterile petridish. The droplet was covered with warm, non toxic mineral oil and incubated at $38^{\circ} \mathrm{C}, 5 \% \quad \mathrm{CO}_{2}, 95 \%$ relative humidity for $24 \mathrm{hrs}$ in $\mathrm{CO}_{2}$ incubator (Nuaire, USA). The experiment was repeated 6 times for each group as replicates.

The selected oocytes were cultured in TCM 199 medium containing 10\%FCS, $0.3 \%$ BSA and $10 \mathrm{IU} / \mathrm{ml}$ of hCG with different supplements as shown in Table No 1.

\section{In vitro fertilization}

\section{Sperm preparation for in vitro fertilization}

Semen straw was thawed in warm water (35$37^{\circ} \mathrm{C}$ ) for $1 \mathrm{~min}$ and was emptied in to $15 \mathrm{ml}$ tube add $5 \mathrm{ml}$ of sperm TALP medium
(Appendix IIIa) and centrifuged at 800-1000 rpm for $5 \mathrm{~min}$. The supernatant was removed and process was repeated again by adding $5 \mathrm{ml}$ sperm TALP. Sperm pellet was formed finally after discarding the supernatant. Sperm pellet was dissolved in $1 \mathrm{ml}$ of fertilization TALP (Appendix IIIb), kept in $\mathrm{CO}_{2}$ incubator for $30 \mathrm{~min}$ before inseminating the matured oocytes. The sperm concentration was adjusted to $4-5 \times 10^{6}$ cell $/ \mathrm{ml}$.

\section{In vitro fertilization of matured oocytes}

The expanded cumulus cells of Invitro matured oocytes were removed by washing (only degree1 and 2 of cumulus cell expansion) several time with fertilization TALP. Denuded oocytes were transferred to $60 \mu 1$ droplet of fertilization TALP medium in $35 \mathrm{~mm}$ sterile petridish and were inseminated with $40 \mu \mathrm{l}$ of processed spermatozoa. The droplet was covered with sterile mineral oil and kept in $\mathrm{CO}_{2}$ incubator at $38^{\circ} \mathrm{C}, 5 \% \mathrm{CO}_{2}$, $90-95 \% \mathrm{RH}$ ) for $18 \mathrm{~h}$.

\section{In vitro culture of fertilized oocytes and assessment of cleavage rate}

After $18 \mathrm{~h}$ of sperm oocyte co-incubation, oocytes were washed several times with $\mathrm{mSOF}$ to remove attached and died spermatozoa from fertilized oocytes and washed oocytes were cultured in modified synthetic Oviductal fluid (mSoF) (appendix IV) supplemented with $0.8 \%$ bovine serum albumin (BSA), essential and nonessential amino acids.

Cleavage rate was observed after $96 \mathrm{~h}$ culture at $38^{\circ} \mathrm{C}, 5 \% \mathrm{CO}_{2}, 90-95 \% \mathrm{RH}$. Cleavage rate was calculated by dividing total number cleaved oocytes (2-4 cell stage embryos) at $96 \mathrm{~h}$ with number of oocytes utilized for in vitro fertilization and expressed in percent cleavage rate. 
Cleavage rate $(\%)=$

Total number of cleaved oocytes

Number of oocytes utilized for in vitro
fertilization

\section{Statistical data analyses}

The data was subjected to statistical analysis using General Linear Model (GLM) procedures SAS 9.3 to assess the significant difference at $5 \%$ level of significance between different supplements cleavage rate.

\section{Results and Discussion}

Present study was carried out to compare the efficacy of serum gonadotrophin, estrodiol$17 \beta$, estrus buffalo serum and buffalo follicular fluid supplementation on cleavage rate of buffalo oocytes. Ovaries were collected from buffalo of unknown reproductive status slaughtered in local abattoir. Collected ovaries were processed by washing with normal saline solution and phosphate buffer saline for aseptic collection of oocytes (Plate 1).

The cumulus oocyte complexes (COC) along with follicular fluid were pooled into $50 \mathrm{ml}$ sterile plastic tube and were allowed to settle for 10 minutes. The sediments were taken in large petridish for searching and grading the oocytes. In vitro maturation was carried out for collected culturable oocytes by using maturation media containing supplements in different concentration as per experimental design ( $\mathrm{T} 1$ to $\mathrm{T} 8$ ) separately under laminar flow taking all precaution to avoid any bacterial and fungal contamination. In vitro fertilization was done for the matured oocytes after removing the expanded cumulus cells using capacitated spermatozoa and assessed the IVF rate by noting the cleavage rate after $96 \mathrm{~h}$ of culture in modified synthetic oviductal fluid.
The results of this study describe the cleavage rate achieved by maturing the oocytes in different supplemental groups are presented in this chapter.

\section{Cleavage rate}

In vitro fertilization was carried out for the matured oocytes after removing the expanded cumulus cells completely. Semen sample was processed for capacitating the spermatozoa and finally inseminate the denuded oocytes with capacitated spermatozoa. Cleavage rate was calculated by dividing total number cleaved oocytes (2-4cell stage embryos) at $96 \mathrm{~h}$ by number of oocytes utilized for in vitro fertilization.

The number fertilized oocytes that reached 2 cell stages were 5/53,7/55, 4/49, 4/46, 6/55, $8 / 55,3 / 50$, and $4 / 48$ respectively for serum gonadotrophin @ @50IU/ml, serum gonadotrophin @ 100IU/ml, estradiol-17 $\beta$ $@ 0.5 \mu \mathrm{g} / \mathrm{ml}$, estradiol-17 $@ @ 1 \mu \mathrm{g} / \mathrm{ml}, 5 \%$ estrus buffalo serum, $10 \%$ estrus buffalo serum, 5\% buffalo follicular fluid and 10\% buffalo follicular fluid supplemented groups respectively. Similarly the number of oocytes that reached 4 cell stage of cleavage was $2 / 53$, $2 / 55,1 / 49,0 / 46,4 / 55,3 / 55,1 / 50$, and $0 / 48$ respectively for $\mathrm{T} 1, \mathrm{~T} 2, \mathrm{~T} 3, \mathrm{~T} 4, \mathrm{~T} 5, \mathrm{~T} 6, \mathrm{~T} 7$ and $\mathrm{T} 8$ groups.

The cleavage rate was calculated by considering the oocytes that reached 2-cell and 4-cell stage of cleavage together (Plate 8). The mean percentage values of cleavage rate in serum gonadotrophin @ $50 \mathrm{IU} / \mathrm{ml}$, serum gonadotrophin@100IU/ml, estradiol-17 $\beta$ $@ 0.5 \mu \mathrm{g} / \mathrm{ml}$, estradiol-17 $\beta @ 1 \mu \mathrm{g} / \mathrm{ml}, 5 \%$ estrus buffalo serum, $10 \%$ estrus buffalo serum, 5\% buffalo follicular fluid and $10 \%$ buffalo follicular fluid supplemented group were $12.98 \pm 1.07,16.36 \pm 3.27,8.51 \pm 2.76$, $9.09 \pm 2.97, \quad 18.23 \pm 1.98, \quad 20.00 \pm 0.87$, $8.27 \pm 2.70$ and $7.98 \pm 2.59$ respectively (Plate $10)$. 
In the present experiment, highest cleavage rate was shown by the oocytes cultured in IVM medium supplemented with $10 \%$ estrus buffalo serum and the lowest cleavage rate was observed in the oocytes supplemented with $10 \%$ buffalo follicular fluid. The statistical analysis of the data revealed that cleavage rate was significantly $(\mathrm{p} \leq 0.05)$ higher in the group supplemented with $5 \%$ estrus buffalo serum and $10 \%$ estrus buffalo serum as compared to all other groups of the experiment. Though the mean cleavage rate in serum gonadotrophin supplemented groups at both the concentrations was more than that in estradiol-17 $\beta$ and buffalo follicular fluid supplemented groups, statistically there was no significant difference between groups supplemented with serum gonadotrophin, estradiol-17 $\beta$ and buffalo follicular fluid.

The comparison of mean values of cleavage rate between two different concentrations of each supplement suggested that there was no significant $(\mathrm{p} \leq 0.05)$ difference between serum gonadotrophin@50IU/ml and @ $100 \mathrm{IU} / \mathrm{ml}$, estradiol-17 $\beta @ 0.5 \mu \mathrm{g} / \mathrm{ml}$ and $@ 1 \mu \mathrm{g} / \mathrm{ml}, 5 \%$ and $10 \%$ estrus buffalo serum, 5\% and 10\% buffalo follicular fluid.

\section{Serum gonadotropin}

Supplementation of serum gonadotrophin@100IU/ml to IVM medium showed better cytoplasmic maturation rate and cleavage rate though there was no significant effect in terms of nuclear maturation where as supplementation of the same@50IU/ml did not show much beneficial effects. The beneficial effects of gonadotrophins could be attributed to the fact that they are the primary regulators of oocyte maturation in mammalian oocytes in vivo and one of the functions of its preovulatory surge is to suppress the granulosa cell factor that inhibits meiosis (Umadevi, 1997).. Faraget al., (2013) showed that the supplementation of gonadotrophin (PMSG-hCG) to culture

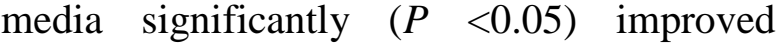
meiotic maturation rate of camel denuded oocytes than that cultured in hormone-free media. Caprine oocytes matured with 20IU/ml PMSG had a good cytoplasmic maturation rate that allows normal embryo development up to blastocyst stage (Kouamo and Kharche, 2015)

\section{Estrodiol-17 $\beta$}

The cleavage rate in the oocytes supplemented with estradiol-17 $\beta$ at both the concentration was better than the supplementation of $10 \%$ buffalo follicular fluid. This inhibitory effect of Estradiol-17 $\beta$ on oocyte maturation is observed by McGaughey (1977) in pigs, Eppig and Koide (1978) and Dianne and Tenney (1980) in mouse. Estradiol-17 $\beta$ inhibited the cAMP phosphordiesterase activity of mouse oocyte in a concentration-dependent manner (Kaji, 1987). This finding provides an explanation for the inhibitory effect of steroid hormones on germinal vesicle breakdown (GVBD) of mouse oocytes in vitro.

Similar to the present results Tesariket al., (1995) reported that in humans the addition of E2 to oocyte maturation medium did not produce any apparent effects on either germinal vesicle breakdown or further progression of meiosis, but it did increase the fertilization and cleavage rates of the in vitro matured oocytes. Bekeret al., (2002) matured bovine oocytes in TCM199 in the presence of $1 \mu \mathrm{g} / \mathrm{ml}$ E2 with or without $0.05 \mathrm{IU} / \mathrm{ml}$ recombinant hFSH. They concluded that supplementation of $1 \mu \mathrm{g} / \mathrm{ml} \mathrm{E} 2$ to a serum free maturation medium negatively affects bovine oocyte nuclear maturation and subsequent embryo development and these negative effects of E2 could be attenuated in the presence of FSH. 


\section{Estrus buffalo serum}

The mean values of cleavage rate were $21.12 \pm 1.98$ and $23.52 \pm 0.87$ respectively in the oocytes matured in IVM supplemented with $5 \%$ and $10 \%$ estrus buffalo serum respectively. Among the eight experimental groups under study the mean values of cleavage rate were highest in the oocytes cultured in IVM medium supplemented with $10 \%$ estrus buffalo serum. The beneficial effect of supplementation of estrus buffalo serum to IVM medium on oocyte maturation and subsequent better cleavage rate could be attributed to the fact that estrus buffalo serum contains various hormones like FSH, LH and E2. Biological role of estrus serum is to compensate for whatever essential elements are missing from the medium by serving as a reservoir for many of the beneficial components, such as different energy substrates, steroids, amino acids, fatty acids, vitamins and growth factors. Serum also serves as a protective compound against scavenging ions and small molecules secreted from the developing embryo. Similarly, Toteyet al., (1992) observed higher rates of maturation and development to the blastocyst stage in the buffalo oocytes cultured in medium supplemented with EBS and gonadotrophin. Karami et al., (2010) reported high maturation, fertilization and embryo development rate of ovine oocytes in human menopausal serum, estrous sheep serum, and estrous goat serum, than ovine follicular fluid, bovine follicular fluid and control media.

\section{Buffalo follicular fluid}

The mean values of cleavage rate were $8.27 \pm 2.70$ and $7.98 \pm 2.59$ respectively in the oocytes matured in IVM medium supplemented with $5 \%$ and $10 \%$ buffalo follicular fluid respectively. Among all the experimental groups the lowest cleavage rate was observed in the oocytes supplemented with $10 \%$ buffalo follicular fluid. The observation of Stephen et al., (1984) that the follicular fluid transiently suppresses the germinal vesicle breakdown (GVBD) in mouse oocytes by elevating cAMP in the oocyte cumulus cell complex supports the present findings. However these results are in contrast to the findings of Masudul et al., (2012) who concluded that that the GFF has a positive effect on in vitro production of embryos in Black Bengal goats and a $10 \%$ level of GFF is recommended based on the improvements observed and the associated economic benefits. Maria et al., (2014) evaluated the influence of follicular fluid added to the maturation medium on the quality of bovine embryos produced in vitro. Even though higher concentration of follicular fluid added to the maturation medium reduced embryonic development rates, in lower concentrations, follicular fluid contributed to increases in inner cell mass number. They concluded that, follicular fluid added to the maturation medium enhances the number of cells in bovine embryos produced in vitro, especially for inner cell mass. The discrepancy in the results of present experiment with others may be because of variations in the size and maturational status of the follicles from which the follicular fluid was collected. Because, Ayoub and Hunter (1993) collected bovine follicular fluid at different stages of the estrous cycle from small, medium, and large follicles. Follicular fluid from both small and medium follicles at estrus had the greatest ability to prevent germinal vesicle breakdown but became less potent at postestrus. Follicular fluid from large follicles at estrus had less ability to inhibit germinal vesicle breakdown than fluid from small and medium follicles. However, follicular fluid from large follicles had less germinal vesicle breakdown inhibiting activity at proestrus than follicular fluid from large follicles at late metestrus, early diestrus, and mid diestrus. 
Table.1 Composition and supplements of the maturation media in different groups

\begin{tabular}{|c|c|c|}
\hline Groups & Supplements & Detailed Composition of maturation medium \\
\hline T1 & $\begin{array}{l}\text { Serum Gonadotrophin } \\
\text { @ } 50 \mathrm{IU} / \mathrm{ml}\end{array}$ & $\begin{array}{l}\text { TCM 199+10\% FCS+ } 0.3 \% \text { BSA+ hCG } \\
\text { @ 10IU/ml + serum gonadotrophin @ } 50 \mathrm{IU} / \mathrm{ml}\end{array}$ \\
\hline $\mathbf{T 2}$ & $\begin{array}{l}\text { Serum Gonadotrophin } \\
\text { @ } 100 \mathrm{IU} / \mathrm{ml}\end{array}$ & $\begin{array}{l}\text { TCM 199+10\% FCS+ } 0.3 \% \text { BSA+ hCG } \\
\text { @ 10IU/ml + serum gonadotrophin @ 100IU/ml }\end{array}$ \\
\hline T3 & 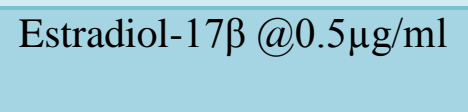 & $\begin{array}{l}\text { TCM 199+10\% FCS+ 0.3\% BSA+ hCG } \\
@ 10 \mathrm{IU} / \mathrm{ml}+\text { Estradiol-17 } @ 0.5 \mu \mathrm{g} / \mathrm{ml}\end{array}$ \\
\hline T4 & Estradiol-17 $\beta @ 1 \mu \mathrm{g} / \mathrm{ml}$ & $\begin{array}{l}\text { TCM 199+10\% FCS+ 0.3\% BSA+ hCG } \\
\text { @ 10IU/ml + Estradiol-17 @ @ } 1 \mu \mathrm{g} / \mathrm{ml}\end{array}$ \\
\hline T5 & $5 \%$ Estrous buffalo serum & $\begin{array}{l}\text { TCM } 199+10 \% \text { FCS+ } 0.3 \% \text { BSA+ hCG } \\
\text { @ } 10 \mathrm{IU} / \mathrm{ml}+5 \% \mathrm{EBS}\end{array}$ \\
\hline T6 & $\begin{array}{l}10 \% \text { Estrous buffalo } \\
\text { serum }\end{array}$ & $\begin{array}{l}\text { TCM 199+10\% FCS+ } 0.3 \% \mathrm{BSA}+\mathrm{hCG} \\
@ 10 \mathrm{IU} / \mathrm{ml}+10 \% \mathrm{EBS}\end{array}$ \\
\hline T7 & $5 \%$ Buffalo follicular fluid & $\begin{array}{l}\text { TCM } 199+10 \% \mathrm{FCS}+0.3 \% \mathrm{BSA}+\mathrm{hCG} \\
\text { @ } 10 \mathrm{IU} / \mathrm{ml}+5 \% \mathrm{BFF}\end{array}$ \\
\hline T8 & $\begin{array}{l}\text { 10\% Buffalo follicular } \\
\text { fluid }\end{array}$ & $\begin{array}{l}\text { TCM 199+10\% FCS+ } 0.3 \% \mathrm{BSA}+\mathrm{hCG} \\
\text { @ } 10 \mathrm{IU} / \mathrm{ml}+10 \% \mathrm{BFF}\end{array}$ \\
\hline
\end{tabular}

Table.2 Cleavage rate (\%) of in vitro fertilized buffalo oocytes matured in IVM medium with different supplements (Mean \pm SE)

\begin{tabular}{|c|c|c|c|c|c|}
\hline \multirow[t]{2}{*}{ Groups } & \multirow[t]{2}{*}{$\begin{array}{c}\text { No. of } \\
\text { replicate }\end{array}$} & \multirow{2}{*}{$\begin{array}{c}\text { Number of } \\
\text { matured } \\
\text { oocytes utilized }\end{array}$} & \multicolumn{2}{|c|}{$\begin{array}{c}\text { Total number of } \\
\text { cleavage }\end{array}$} & \multirow[t]{2}{*}{ Cleavage rate } \\
\hline & & & 2 cell & 4 cell & \\
\hline $\mathbf{T 1}$ & 6 & 53 & 5 & 2 & $12.98 \pm 1.07^{\mathrm{abc}}(7)$ \\
\hline $\mathbf{T} 2$ & 6 & 55 & 7 & 2 & $16.36 \pm 3.27^{\mathrm{abc}}$ \\
\hline T3 & 6 & 49 & 4 & 1 & $8.51 \pm 2.76^{c}(5)$ \\
\hline T4 & 6 & 46 & 4 & 0 & $9.09 \pm 2.97^{\mathrm{c}}(4)$ \\
\hline T5 & 6 & 55 & 6 & 4 & $18.23 \pm 1.98^{\mathrm{a}}(10)$ \\
\hline T6 & 6 & 55 & 8 & 3 & $20.00 \pm 0.87^{\mathrm{a}}(11)$ \\
\hline $\mathbf{T 7}$ & 6 & 50 & 3 & 1 & $8.27 \pm 2.70^{c}(4)$ \\
\hline T8 & 6 & 48 & 4 & 0 & $7.98 \pm 2.59^{c}(4)$ \\
\hline
\end{tabular}

a,b,c: Mean values of Cleavage rate with different superscripts differ significantly ( $\mathrm{p} \leq 0.05)$ 
Int.J.Curr.Microbiol.App.Sci (2020) 9(2): 2072-2084

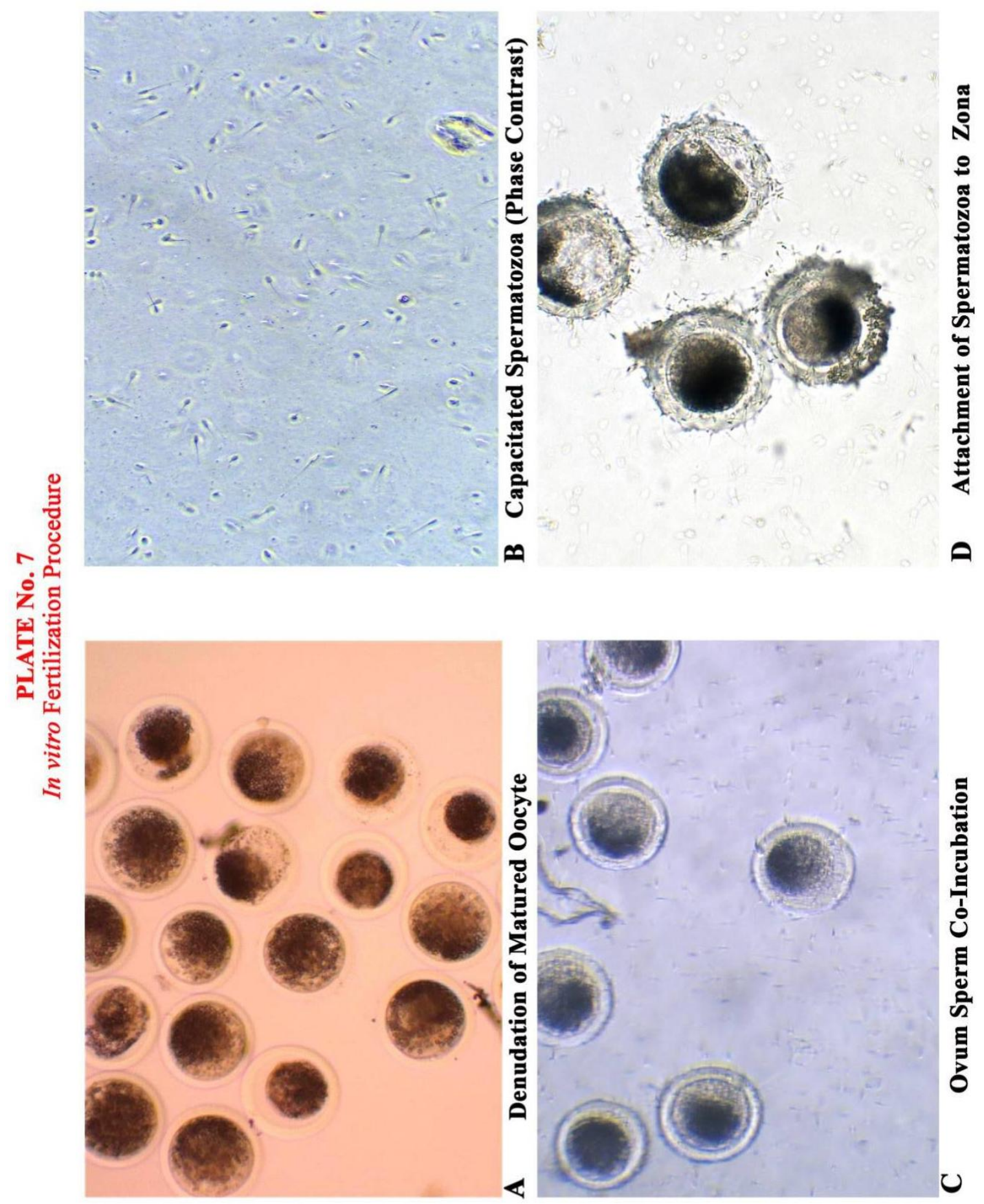




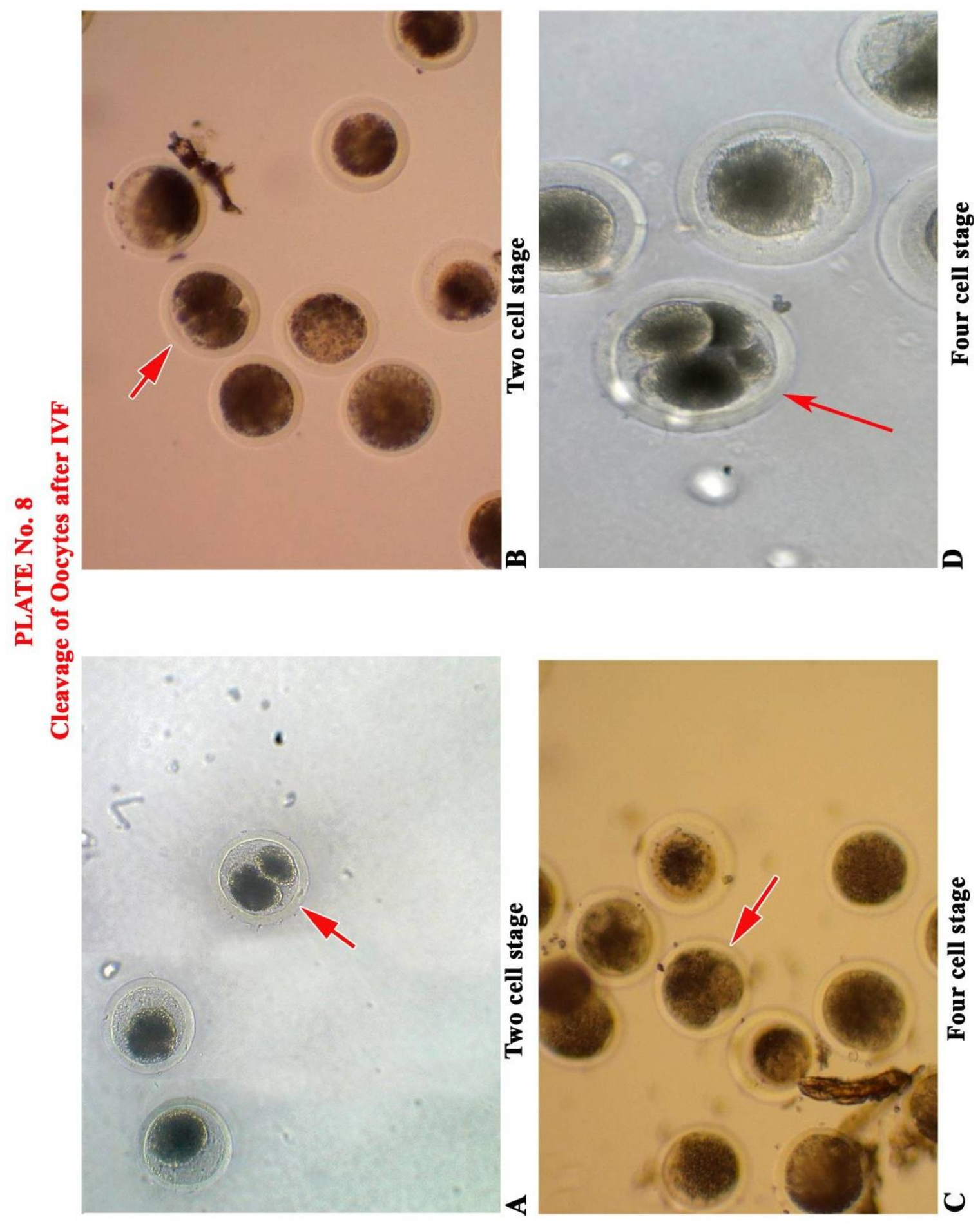




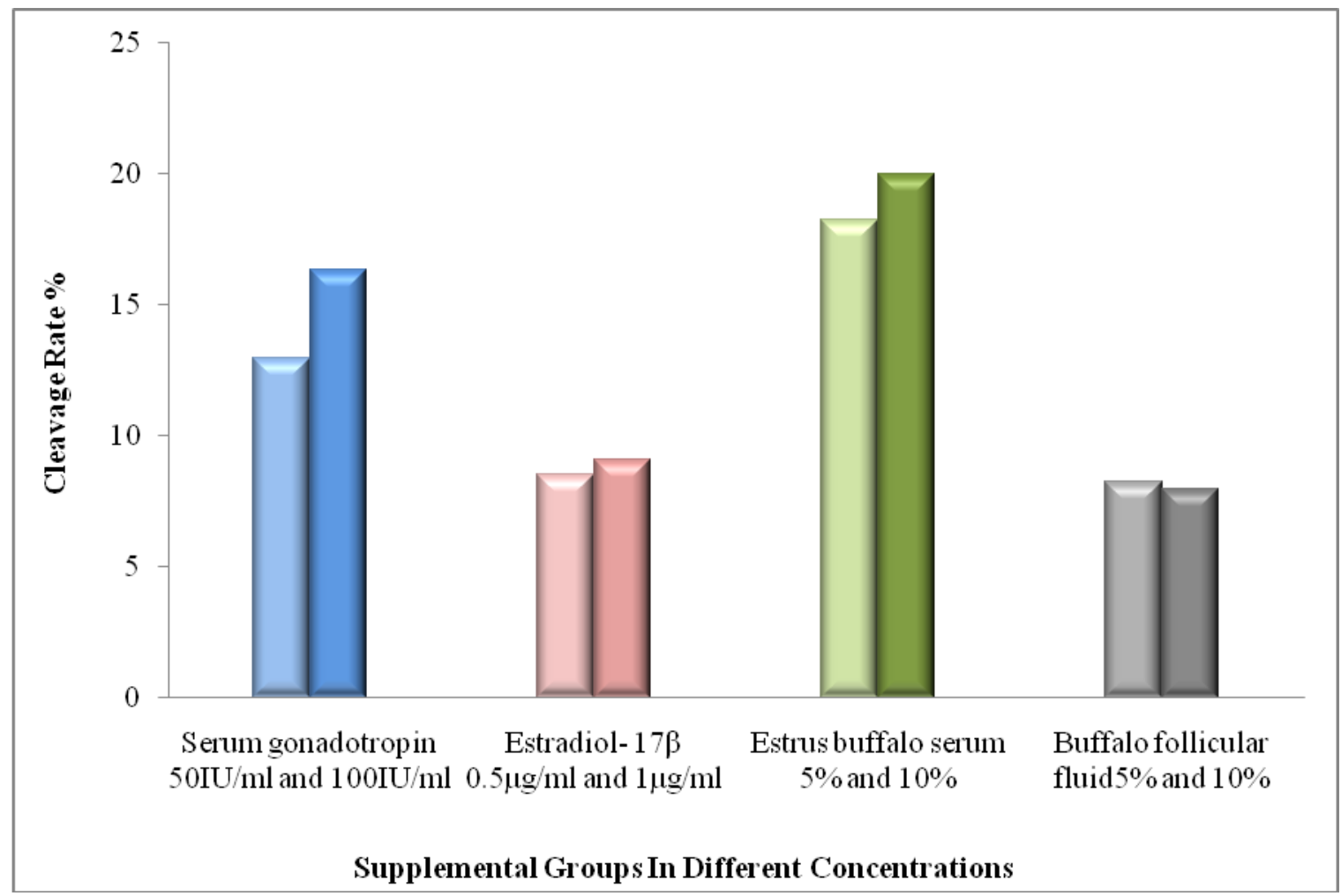

\section{References}

Abid Mehmood., Muhammad Anwar., Sayed Murtaza Hassan Andrabi., Muhammad Afzal. and Syed Muhammad Saqlan Naqvi., 2008. In vitro maturation and fertilization of bufflooocytes: the effect of recovery and maturation methods. Tur. J. Vet. Anim. Sci., 35(6): 381-386

Agrawal, K.P., Sharma, T., Sexana, C. and Sharma, N., 1995. Chronology of first meiotic events of caprine oocytes matured in vitro. Indian. J. Anim. Sci., 65:285-288

Aguilar, J.J., Woods, G.L., Miragaya, M.H., Olsen, L.M. and Vanderwall, D.K., 2001. Effect of homologous preovulatory follicular fluid on in vitro maturation of equine cumulus-oocyte complexes. Theriogenology., 57: 745-58

Algriany, O., Bevers, M., Schoevers, E., Colenbrander, B. and Dieleman, S., 2004. Follicle size dependent effects of sow follicular fluid on in vitro cumulus expansion, nuclear maturation and blastocyst formation of sow cumulus oocytes complexes. Theriogenology., 62: 1483-1497.

Ayoub, M. A. and Hunter, A. G., 1993. Inhibitory effect of bovine follicular fluid on in vitro maturation of bovine oocytes. J. Dairy. Sci., 76: 95-100

Balain, D.S., 1999. Inflow and outflow of buffalo germplasm resources and their global contribution. Invited papers presented in short course on "characterization and conservation of domesticated livestock and poultry resources". 10-19 May, 1999, National Bureau of Animal Genetic Resources (ICAR), Karnal.

Beker, A.R.C.L., Colenbrander, B. and Bevers, M.M., 2002. Effect of 17- $\beta$ estradiol on the in vitro maturation of bovine oocytes. Theriogenology., 58(9): 1663-1673

Department of Animal Husbandry, Dairying and Fisheries, 2014. Basic animal husbandry and fisheries statistics. Ministry of agriculture krishibhawan, 
New Delhi

Dianne Moore Smith. and Tenney, D. Y., 1980. Effects of steroids on mouse oocyte maturation in vitro. J. Reprod. Fert., 60: 331-338

Kaikini, A.S., 1992. Dimensions of infertility or sterility in cattle and buffaloes. Indian J. Anim. Reprod., 13: 10

Kouamo, J. and Kharche, S.D., 2015. Effect of different gonadotropinon in vitro on development of immature caprine oocytes. Ind. J. Anim. Reprod., 36 (1): 5-9

Kumar, D. and Anand, T., 2012.In vitro embryo production in buffalo: basic concepts. J. Buff. Sci., 1: 50-54

Mahmoud, G.M. and Nawito, M.F., 2003. Cytogenetic evaluation of in vitro matured buffalo oocytes in different culture condition. Egypt. J. Vet. Sci., 37: 105-116

Mcgaughey, R.W., 1977.The culture of pig oocytes in minimal medium, and the influence of progesterone and estradiol17beta on meiotic maturation. Endocrinology., 100(1):39-45.

Pankaj A. Patel., Sandhya, S. Chaudhary., Gopal Puri., Virendra Kumar Singh. and Arjun B. Odedara., 2015. Effects of $\beta$ mercaptoethanol on in vitro maturation and glutathione level of buffalo oocytes. Vet. World., 8(2):213-216

Romero-Arredondo, A. and Seidel, G.E., 1996. Effects of follicular fluid during in vitro maturation of bovine oocytes on in vitro fertilization and early embryonic development. Biol. Reprod., 55: 1012-1016
Stephen M. Downs., Douglas, L. Coleman., Patricia, F., Ward-Bailey and John J. Eppig., 1984. Hypoxanthine is the principal inhibitor of murine oocyte maturation in a low molecular weight fraction of porcine follicular fluid. Proc. Natl. Acad. Sci. USA., 82: 454-458

Tesarik, J and Mendoza, C. J., 1995. Nongenomic effects of 17 beta-estradiol on maturing human oocytes: relationship to oocyte developmental potential. Clin. Endocrinol. Metab., 80(4):1438-43

Tomek, W., Torner, H. and Kanitz, W., 2002. Comparative analysis of protein synthesis transcription and cytoplasmic polyadenylation of mRNA during maturation of bovine oocytes in vitro.Rep. Dom. Anim., 37: 86-91

Totey, S.M., Daliri, M., Appa Rao, K.B.C., Pawshe, C.H., Taneja, M. and Chillar, R.S., 1996. Differential cleavage and developmental rates and their co relation with cell numbers and sex ratios in buffalo embryos generated in vitro. Theriogenology.,39: 887-898

Totey, S.M., Singh, G., Taneja, M., Pawshe, C.H. and Talwar, G.P., 1992. In vitro maturation, fertilization and development of follicular oocytes from buffalo (Bubalus bubalis). J. Reprod. Fertil., 95(2): 597-607

Uma Devi, S., 1997. Influence of various sera and hormone supplementation on in vitro maturation of buffalo oocytes. Thesis submitted to Dept. of Vet. Gyna. Obst. Veterinary College Bangalore.

\section{How to cite this article:}

Ambadas, K. Shrikant, G. Sarvadnya and Satish, K. B. 2020. Comparison of Cleavage Rate of Buffalo Oocytes on Supplementing with Different Concentration of Serum Gonadotropin, Estradiol 17b, Estrus Buffalo Serum and Buffalo Follicular Fluid. Int.J.Curr.Microbiol.App.Sci. 9(02): 2072-2084. doi: https://doi.org/10.20546/ijcmas.2020.902.235 